\title{
The Impact of Students' Initial Decisions in Choosing Tertiary Institutions Towards Student Satisfaction on Learning Quality
}

\author{
Kartin Aprianti* \\ Institute of Economic Science Bima \\ Bima, Indonesia \\ kartinaprianti93@gmail.com
}

\author{
Amirulmukminin Amirulmukminin \\ Institute of Economic Science Bima \\ Bima, Indonesia \\ Amirul.stiebima@gmail.com
}

\author{
Muhammad Yusuf \\ Institute of Economic Science Bima \\ Bima, Indonesia \\ yusufzm.stiebima@gmail.com
}

\begin{abstract}
The increasingly fierce competition in higher education is marked by the emergence of a variety of new tertiary institutions which certainly influences the decision of prospective students to choose a quality tertiary institution. Tertiary institutions must be able to provide a quality and meaningful learning process. This research aims to reveal the role of student's initial decisions to choose a tertiary institution that is proxied through physical evidence and self-motivation as well as to reveal the impact of those decisions on student satisfaction with the quality of learning. The research was conducted through a survey. The samples in this research were active students at private tertiary institutions in Bima city which were 379 respondents in which the Proportionate Stratified Random Sampling technique was used. Regression analysis with the help of SPSS Version 20 for windows was used to analyze the data and test the hypothesis. The results indicated that aspects of physical evidence and self-motivation had: a role in the initial decision to choose a tertiary institution and the decision had an impact on student satisfaction with the learning quality of the chosen tertiary institution. The implications of this research are directed to maximize the dimensions that influence students' initial decisions in choosing a tertiary institution in order to optimize student satisfaction on the quality of learning starting from the input, process and output of learning-oriented to the service aspects that are directly felt by students as recipients of educational services.
\end{abstract}

Keywords- physical evidences, student motivation, learning quality

\section{INTRODUCTION}

The decision of which tertiary institution to choose by prospective students is likened to a buyer who will buy an item or product. Therefore, higher education can be analogically said as an institution providing services to students. Based on observations made by researchers, some students make spontaneous choices without good planning in which they are tempted by promotions, services, building facilities, etc. without prioritizing whichever is done first. Several students realize that the decisions taken are not as expected when they are still running two or three semesters. This proves that the decision on choosing a tertiary institution requires a rational process as objective as possible, since it will have long-term consequences and be associated with great sacrifices such as time preparation, funds, and mental attitude of the student.

A tertiary institution is expected to realize the important factors which may motivate their students and to provide information regarding its product which will be useful for students. In this research the initial decision of students in choosing tertiary institutions was proxied through the physical evidence of the tertiary institution along with student self-motivation.

The physical evidence of a tertiary institution serves as evidence that the tertiary institution provides a meaningful and quality learning process. Sutartiah revealed that one of the strategies to increase the advantage in competing for attracting public interest is by continuing to improve the quality of physical evidence [1].

Fitria explains that internal factors also play a role for prospective students in determining tertiary institutions [2]. One of the internal factors is self-motivation. Before deciding to choose a tertiary institution, prospective students usually have achievement targets such as job opportunities, desire to excel, or affected by the wishes of their parents. Those targets are considered as a motivation for prospective students to make their choices.

Once the tertiary institution is decided, students begin to feel its products or services, one of which is through learning activities. Students certainly expect the selected tertiary institution to provide satisfying services that is to develop their interests and talents.

Fitria described that the most dominant factor which influences students' decision to choose tertiary institution was student self-motivation while Sutartiah revealed that the physical evidence of tertiary institution ranked first in influencing the student's decision [1], [2].

The Explains that the quality services which include physical evidences affect student satisfaction [3]. This is in line with the research conducted by Kristina and Dewi Yohanna that academic services consisting of physical facilities of tertiary institutions greatly influence student academic satisfaction [4]. In addition, defines that the level of student satisfaction is strongly influenced by facilities [5]. This shows that the decision of students when choosing a tertiary institution is very likely to be influenced by the quality of service because it has an impact on student satisfaction with the quality of learning provided by the tertiary institution.

The essence of educational institutions is teaching and learning activities (learning process). Quality as a "place to use" and emphasizes that the basic purpose of the quality 
of an educational institution is "developing programs and services that meet the needs of its users such as students and the community" [6].

Quality learning boils down to the ability of educators in the learning process. It simply means the ability that must be possessed by educators to be able to plan the learning that covers the learning process and evaluation [7]. Students certainly expect selected tertiary institutions to provide satisfying services to be able to develop their interests and talents. Satisfaction toward the quality of learning intended in this research is the suitability of learning activities carried out by educators with the needs and expectations of students.

In contrast to previous researches which only analyzed the effect of physical evidence and self-motivation on the decision of choosing a tertiary institution which separately discussed, this research finds that physical evidence and self-motivation play a partial and simultaneous role in the initial decision of students in choosing a tertiary institution and reveals the impact of these decisions on student satisfaction with the learning quality. The final results of the research are based on the increase of student satisfaction toward the learning quality at selected tertiary institutions.

Research on the physical evidence of higher education and self-motivation becomes important to analyze considering consumers (community/students) tend to consider the physical form before deciding the tertiary institution to choose, which means considering whether the tertiary institution is appropriate or not for the convenience and smoothness of the learning and teaching process. Physical evidence of a good tertiary institution can motivate students to strengthen their decision that creates trust in the chosen tertiary institution. This decision has an impact on whether or not consumers are satisfied with the quality of learning provided by selected tertiary institutions, remembering that the essence of educational institutions is to provide the best meaningful services and quality for both teaching and learning processes.This template, modified in MS Word 2007 and saved as a "Word 97-2003 Document" for the PC, provides authors with most of the formatting specifications needed for preparing electronic versions of their papers. All standard paper components have been specified for three reasons: (1) ease of use when formatting individual papers, (2) automatic compliance to electronic requirements that facilitate the concurrent or later production of electronic products, and (3) conformity of style throughout a conference proceedings. Margins, column widths, line spacing, and type styles are built-in; examples of the type styles are provided throughout this document and are identified in italic type, within parentheses, following the example. Some components, such as multi-leveled equations, graphics, and tables are not prescribed, although the various table text styles are provided. The formatter will need to create these components, incorporating the applicable criteria that follow.

\section{RESEARCH METHOD}

This research is quantitative in nature which used survey research methods. The research was conducted at four different Higher Education in Bima city. The population in this research was 7,200 active students in the 2017/2018 school year at STIE (Economic Science) Bima, STIH (Legal Research) Muhammadiyah Bima, STKIP (Teaching and Education) Bima and STISIP (political and social science) Bima.

The sampling technique used is probability sampling, which is the Proportionate Stratified Random Sampling technique. In order to determine the sample size, this research used the Slovin formula with a significance level of 5\% which makes the total samples were 379 students. The data were collected through direct techniques that were providing questionnaires (40 statement items) and then filled in by the respondents. Data analysis and hypothesis testing used regression analysis with the help of SPSS Version 20 for windows.

\section{RESULTS AND DISCUSSION}

Suharsimi states that a good regression equation model is one that has fulfilled the classic assumption test that is all data are normally distributed, the model that is free from multicollinearity and heteroscedasticity [8]. Based on the results of the classical assumption test it has been proven that the research model meets the classical assumption requirements so that it is considered good.

Hypothesis 1 (H1) indicated that physical evidence has a role in the initial decision to choose tertiary institutions, where $t_{\text {test }}=2,540$ with significance of $0.011<0.05$. Therefore, the hypothesis is accepted. The results of this research support the results of the research conducted by rakhman which states that physical evidence contributes to the initial decision in choosing tertiary institutions [9].

Hypothesis 2 (H2) indicated that self-motivation variables play a role in the initial decision to choose a private tertiary institution in the City of Bima, where $t_{\text {test }}=12,685$ with significance of $0.000<0.05$. Therefore, the hypothesis is accepted. These results are in line with the research conducted by puspitasari which states that self-motivation is the dominant third aspect that influences the initial decision of students in choosing tertiary institutions [10].

Hypothesis 3 (H3) indicated that physical evidence and self-motivation simultaneously contribute to the initial decision to choose private tertiary institutions in the city of Bima, where $F_{\text {test }}=144,605$ with significance of 0.000 $<0.05$. Therefore, hypothesis 3 is accepted. These results support the research conducted by ruhiyat which explains that aspects of physical evidence and self-motivation are the best combination as the most dominant aspect in influencing students' initial decision in choosing tertiary institutions [11].

Hypothesis $4(\mathrm{H} 4)$ indicated that the initial decision of a student in choosing a college has an impact on student satisfaction with the quality of learning. where $t_{\text {test }}=14,447$ with significance of $0.000<0.05$. Therefore, hypothesis 4 is accepted. These results support the research conducted by ruhiyat which states that the initial decision to choose a tertiary institution leads to the satisfaction of students as recipients of educational services [11]. 
The amount of physical evidence and self-motivation roles towards the initial decision of students in choosing tertiary institutions is 0.435 . The variable of physical evidence and self-motivation in this research had a high contribution (0.659) to the initial decision of students in choosing tertiary institutions.

Furthermore, this research also revealed $35.6 \%$ in which the students' initial decision in choosing tertiary institutions influences students' satisfaction toward learning quality. The variable of students' initial decision in choosing tertiary institutions in this research had a high contribution (0.579) to student satisfaction with learning quality.

Based on the results of hypothesis $1(\mathrm{H} 1)$, hypothesis 2 $(\mathrm{H} 2)$, hypothesis $3(\mathrm{H} 3)$ and hypothesis $4(\mathrm{H} 4)$, it is clear that the physical evidence of tertiary institutions and selfmotivation have a partial and simultaneous role in the initial decision of students in choosing tertiary institutions and those decisions influence satisfaction of students towards the quality of learning.

\section{CONCLUSION}

Based on the aforementioned data analysis and hypothesis testing, it can be concluded that physical evidence and self-motivation contribute to the initial decision of students in choosing tertiary institutions by $43.5 \%$.

The results of this research indicate that in order to optimize student satisfaction toward the quality of learning, maintenance and improvements of physical evidence as an external factor are needed. This can strengthen internal factor that is self-motivation. Therefore, it may provide a greater role to the initial decision in choosing tertiary institutions.

Moreover, the physical evidence and self-motivation are not stand-alone aspects, but rather are integrated and affect the initial decision of students in choosing tertiary institutions. In other words, these aspects should be put together in order to create a learning experience that may improve students' satisfaction.

Optimizing student satisfaction with the quality of learning by considering aspects that influence students' initial decisions in choosing a tertiary institution proves that those decisions are affected by many different factors. For that reason, tertiary institutions need to enhance the quality of educational services in order to increase students' satisfaction.

\section{REFERENCES}

F. Sutariah, "Evaluasi Kepuasan Mahasiswa Terhadap Kualitas Pelayanan Pendidikan Lembaga Pendidikan Tinggi ABC di Cikarang," Form. J. Ilm. Pendidik. MIPA, vol. 7, no. 1, 2017. H. Fitria and E. A. Yani, "Faktor-faktor yang mempengaruhi minat mahasiswa memilih penguruan tinggi ekonomi islam," Stud. Kasus STEI SEBI. J. Ekon. dan Perbank. Syariah, vol. 109, 2014.

[3] A. S. Sri Ratnasari, A. Wijaya, and P. Yeniyati, "Analisis Pengaruh Kualitas Jasa Pelayanan Terhadap Kepuasan Mahasiswa," J. Keuang. dan Bisnis, vol. 17, no. 1, pp. 14-31, 2019.

[4] K. S. Prihatin and Y. S. Dewi, "Pengaruh Pelayanan Akademik Terhadap Tingkat Kepuasan Mahasiswa Universitas Banten Jaya (UNBAJA)," PROGRESS, vol. 2, no. 1, pp. 72-92, 2019.
[5] D. Trisusanti and N. Suryanti, "Pengukuran Tingkat Kepuasan Mahasiswa Terhadap Pelayanan Pendidikan Di Fakultas Keguruan Dan Ilmu Pendidikan," J. Perspekt. Pendidik. dan Kegur., vol. 8, no. 02, pp. 18-27, 2017.

[6] E. Sallis, "Total Quality Management in Education: Manajemen Mutu Pendidikan,” Yogyakarta: IRCiSoD, 2012.

[7] Arifin and Barnawi, Kinerja Guru Profesional. Yogyakarta: Aruzz Media, 2012.

[8] S. Arikunto, "Prosedur penelitian," 2010.

[9] F. Rakhman, "Pengaruh People, Process dan Physical Evidence Terhadap Keputusan Mahasiswa Memilih STIBANKS Al Ma'soem (Tahun Akademik 2017/2018)," J. Ris. Bisnis dan Investasi, vol. 4, no. 3, pp. 10-22, 2018.

[10] A. Puspitasari and F. D. Patrikha, "Analisis Faktor-Faktor Yang Mempengaruhi Keputusan Pemilihan Universitas Pada Siswa Kelas XII SMA Negeri 22 Surabaya," JPEKA J. Pendidik. Ekon. Manaj. dan Keuang., vol. 2, no. 1, pp. 1-10, 2018.

[11] E. Ruhiyat, "Analisis Faktor Yang Menjadi Penentu Mahasiswa Dalam Memilih Perguruan Tinggi,” INOVASI, vol. 3 , no. 1,2017 . 